First Peoples Child \& Family Review

An Interdisciplinary Journal Honouring the Voices, Perspectives, and Knowledges of First Peoples through Research, Critical Analyses, Stories, Standpoints and Media Reviews

\title{
In Memory of Roxanne Charlie
}

Volume 5, Number 1, 2010

URI: https://id.erudit.org/iderudit/1069056ar

DOI: https://doi.org/10.7202/1069056ar

See table of contents

Publisher(s)

First Nations Child and Family Caring Society of Canada

ISSN

1708-489X (print)

2293-6610 (digital)

Explore this journal

Cite this document

(2010). In Memory of Roxanne Charlie. First Peoples Child \& Family Review, 5(1), 9-9. https://doi.org/10.7202/1069056ar viewed online.

https://apropos.erudit.org/en/users/policy-on-use/ 


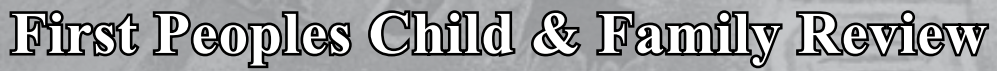

An Interdisciplinary Journal Honoring the Voices, Perspectives and Knowledges of First Peoples through Research, Critical Analyses, Stories, Standpoints and Media Reviews

\section{Volume 5, Number 1, 2010, p. 9}

In Memory of

\section{Roxanne Charlie}

Roxanne Charlie's spirit and essence made its rapid and strong travel over 150 participants at the Gathering and Sharing Wisdom Conference. She was strong in person and is even stronger in spirit. She stood up as protector of her truth and holder of her story. Her story was affirmed by the community and validated by the drumming of a warrior woman song. Roxanne wanted others to benefit and move forward by speaking her truth and knowledge. She carved a space with her words and also extended her wisdom to provide safe passage for others who may have or are walking to that space that brings people into the darkness.

Roxanne Charlie gave of herself generously, fully and completely. Roxanne Charlie speared her place in the earth and spoke her words and wisdom and they will endure on and provide safe passage for others. She demonstrated exceptional heart and courage and the love for family in trying to break cycles of colonization that impact us all. Roxanne Charlie, keep walking with your family, community and with all of us as spirit guide and warrior woman. We dedicate this journal to you, in your memory and spirit. 